\title{
INHIBITION OF YELLOW NUTSEDGE (Cyperus esculentus L.) AND BERMUDAGRASS (Cynodon dactylon (L.) Pers) BY A MULCH DERIVED FROM RYE (Secale cereale L.) IN GRAPEVINES
}

\author{
Juan Ormeño-Núñez ${ }^{1 *}$, Gerardo Pino-Rojas², and Farouk Garfe-Vergara²
}

\begin{abstract}
A B S T R A C T
Two field trials (Los Andes 1998-1999 and Santiago 20042005) were carried out to determine growth inhibition of yellow nutsedge (Cyperus esculentus L.) and bermudagrass (Cynodon dactylon (L.) Pers.), growing on the plantation row, by mulch derived from a rye (Secale cereale L.) cover crop established between grapevine (Vitis vinifera L.) rows on overhead (cv. Flame Seedless) and vertical (cv. Cabernet Sauvignon) training. Spring mowing of the rye sown in the fall allowed for developing a thick and long lasting mulch along the grape rows. Nutsedge and bermudagrass control was 81 and $82 \%$, respectively, and was more effective than conventional chemical (in the row) + mechanical (between rows) control. Glyphosate at $2 \%$ for nutsedge and $1 \%$ for bermudagrass control, applied twice (October and December), was insufficient to control either perennial weed adequately. Total broadleaved and grass/sedge weed control was 67.3 and $43.0 \%$ more effective with the rye mulch than with conventional treatments at Los Andes and Santiago, respectively. Perennial weed control levels could be explained as the new foliage of yellow nutsedge and bermudagrass was particularly susceptible to the shading provided by the rye mulch assembled prior to mid spring shoot emergence, and this effect remained active up until the beginning of autumn. The subsequent rye foliage mowing at the vegetative stage fully expressed the allelopathic effect produced by this local rye cultivar. The use of rye cover crop management and mulch could be applied as an effective weed control technique in conventional, as well as organic deciduous tree orchards.
\end{abstract}

Key words: mulch, cover crop, rye, Cynodon dactylon, Cyperus esculentus, grapevines.

\section{INTRODUCTION}

Weeds that grow in orchards represent one of the main restrictions to the growth and development of the trees. Perennial species that have some type of vegetative reproduction are the most difficult to control, whether by mechanical methods or with herbicides (FAO, 1986). Among this group of invasive weeds, the yellow nutsedge and bermudagrass have been identified as among the most harmful species of weeds at a global level. They are especially problematic when they grow in the tree rows of fruit and vine orchards (Johnson and Talbert, 1989; Ormeño, 2005).

Cover crops planted between orchard rows are an efficient and sustainable alternative to manage the soil in temperate climates. In effect, the use of a cover crop between orchard rows has extensive application, especially in California, USA, where it now covers $20 \%$ of cultivated vineyard areas (Ingels and Klonski, 1998). One of the main applications of cover crops is for the management and control of weeds (Elmore $e t$ al., 1998).

Of the great variety of vegetal species that can be used as cover crops, rye is one of the most appropriate (Bottenberg et al., 1997; Ormeño, 1999). This grass is a winter cereal used marginally as a flour grain and as supplementary forage. It is very rustic, given that not only is it tolerant to low temperatures and soil moisture, but it also posses high foliar and subterranean condition against insects and diseases, and is itself an allelopathic crop on weeds (Barnes and Putnam, 1983;

\footnotetext{
${ }^{1}$ Instituto de Investigaciones Agropecuarias, Centro Regional de Investigación La Platina, Casilla de Correos 439/3, Santiago, Chile. E-mail: jormeno@inia.cl *Corresponding author.

${ }^{2}$ Currently in private activity.

Received: 17 April $2007 . \quad$ Accepted: 31 July 2007.
} 
Barnes et al., 1987). Because of these agro-ecological characteristics, rye has proven to be one of the species with the greatest potential, whether as a pre-crop (Liebl et al., 1992; Yenish et al., 1995) or as a cover crop sown between orchard rows (Bordelon and Weller, 1997; Ormeño, 1999).

Another characteristic of rye is its rapid and deep rooting, a key factor of its high rusticity and capacity to recycle mineral nutrients located deep down the soil surface (Sainju et al., 1998). Masiunas (2006) has recently reviewed the advantages and disadvantages of using rye as a cover crop to control weeds prior to the establishment of fruits and vegetable crops, concluding that this type of cover is an effective way for a sustainable management and control of weeds; unfortunately this review does not cover orchards and vineyards.

The objective of these experiments was to determine the growth inhibiting effects provided by rye sown in autumn between the vineyard rows, on nutsedge growth in a vineyard with overhead training (cv. Flame Seedless) in Los Andes, and on bermudagrass growth in a vineyard with vertical training (cv. Cabernet Sauvignon) in Santiago.

\section{MATERIALS AND METHODS}

\section{Location of the field trials}

The first field trial was conducted during the 19981999 season at the commune of Rinconada, Los Andes Province (32 $43^{\circ}$ ' S, 693 m.a.s.l.), Region of Valparaíso, Chile, on a 15 -yr-old commercial vineyard cv. Flame Seedless, planted at $3.5 \times 3.5$ m overhead trained, which was heavily infested with yellow nutsedge. The soil was a deep Mollisol with a loamy clay texture, belonging to the soil serie Pocuro (2.4\% of OM and pH 6.5).

The second trial was carried out in Santiago during the 2004-2005 season, at La Platina Regional Research Center (333' S625 m.a.s.1.), of the Instituto de Investigaciones Agropecuarias (INIA), Metropolitan Region. This field trial was conducted in a vineyard ( $37 \mathrm{yr}$ ), between the rows of Cabernet Sauvignon vines planted at $3.0 \times 2.0 \mathrm{~m}$ and trained vertically on a California double crosspiece trellis system. The sector had traditionally been managed with harrowing between vine rows, which over the years had favored a heavy infestation by Bermuda grass. The soil was a stony Inseptisol with a loamy texture, belonging to the Mapocho series, with 2.2\% of OM and $\mathrm{pH} 7.4$.

\section{Treatments}

The experimental unit in Los Andes was a row of eight vines, and the treatments used were:

1. Without rye cover and with chemical control to the whole surface with 2.4-D (DMA-6 $668 \mathrm{~g} \mathrm{~L}^{-1}$ acid equivalent SL, Dow Agrosciences, Argentina) mixed with glyphosate (Roundup $480 \mathrm{~g} \mathrm{~L}^{-1} \mathrm{SC}$ Monsanto, Argentina) in doses of $1.0+1.92 \mathrm{~L} \mathrm{ha}^{-1}$ of active ingredient (a.i.), respectively. The mixture was applied on August 10 and was repeated on October 2, 1998. Two additional applications of halosulfuron (Sempra $750 \mathrm{~g} \mathrm{~kg}^{-1} \mathrm{WP}$, Monsanto, Argentina) mixed with glyphosate (Roundup $480 \mathrm{~g} \mathrm{~L}^{-1} \mathrm{SC}$ ) in doses of 0.075 and $0.050+1.92 \mathrm{~L} \mathrm{ha}^{-1}$ a.i. were sprayed. The mixture was applied on December 4, 1998 and was repeated on January 25,1999 . These last two applications were specifically for the control of the yellow nutsedge.

2. Without a rye cover and chemical control in the vine rows and harrowing between the rows, which was the equivalent to the control carried out by the producer, and is considered as a conventional treatment. Herbicide treatments were glyphosate (Roundup $480 \mathrm{~g} \mathrm{~L}^{-1} \mathrm{SC}$ ) at $1.92 \mathrm{~L} \mathrm{ha}^{-1}$ a.i., that was applied on Augusts 18 and 2,4 L ha $^{-1}$ a.i. $(2.5 \% \mathrm{v} / \mathrm{v})$ on December 29, 1998, and sulphosate (Touchdown $500 \mathrm{~g} \mathrm{~L}^{-1} \mathrm{SC}$ Syngenta, Switzerland) at 2.0 $\mathrm{L} \mathrm{ha}^{-1}$ a.i. $(2 \% \mathrm{v} / \mathrm{v})$ sprayed on October 20. Harrowing was carried out with a disk harrow on May 25 of 1998 and January 10 of 1999.

3. Vegetal cover of rye seeded manually between rows. Rye was mowed and plant residues were left in situ.

4. Cover crop of rye sown manually between the rows, subsequently mowed and plant residues were raked onto the vine rows, forming a mulch approximately $1.0 \mathrm{~m}$ wide.

The experimental unit of the test in Santiago, in the vineyard of Cabernet Sauvignon, was composed of a row of five vines. The treatments used were:

1. Rye cover crop sown between grapevine rows; the foliage was mowed and left in situ. No weed control measures were taken on the orchard rows.

2. Rye cover crop in the grapevine inter-rows; the foliage was mowed and left in situ. Glyphosate (Roundup $480 \mathrm{~g}$ $\left.\mathrm{L}^{-1} \mathrm{SC}\right)$ was applied in dosages of $0.96 \mathrm{~L} \mathrm{ha}^{-1}$ of a.i. $(1 \%$ $\mathrm{v} / \mathrm{v}$ ) in the vine row on the same dates as for mowing the rye (September 16 and November 27). 
3. Rye cover crop between rows; plant residues from the mowed foliage were raked onto the vine row forming vegetal mulch on the rows on each plot.

4. Without rye cover crop. Herbicide applications in both on and between grapevine tree rows. Inter-rows management consisted of successive harrowing with a vibro-cultivator (Kuhn, Minnesota, USA) and application of glyphosate (Roundup $480 \mathrm{~g} \mathrm{~L}^{-1} \mathrm{SC}$ ) at $0.96 \mathrm{~L} \mathrm{ha}^{-1}$ a.i. on the same dates as rye mowing (September 16 and November 27).

Mechanical weed control between vine tree rows consisted of harrowing with a vibro-cultivator and/or a tiller on three occasions during the growing season.

\section{Rye cover crop}

In both trials were used seeds from an old cultivar Forrajero, currently maintained as seed mass selection at La Platina Regional Research Center. Seeding at Los Andes was on 11 May 1998 sowing $150 \mathrm{~kg} \mathrm{ha}^{-1}$ broadcasted in all the area and incorporated with raking. In Santiago, rye seeds were broadcasted on 17 June 2004 at $200 \mathrm{~kg} \mathrm{ha}^{-1}$ on small furrows $(17 \mathrm{~cm})$ mechanically made up and then seeds were incorporated using a vibro-cultivator and roller pulled by a tractor. Due to lack of autumn rain, both trial sites were gravity irrigated prior to seeding the rye cover crop.

Rye cover crop foliage at Los Andes was cut three times: 3 October, 2 November and 2 December 1998, each with an average height of $70 \mathrm{~cm}$. A motor-mower (Stihl, manual model FS250, Mönchaltorf, Switzerland) was used, cutting the stubble to a height of $10-15 \mathrm{~cm}$. In Treatment 3 mowed plant matter was left on the soil without removing it, but in Treatment 4, mowed foliage matter from each half of the vine row was manually raked toward the center of the vine row, forming a ridge of vegetal mulch approximately $1.0 \mathrm{~m}$ wide and $10 \mathrm{~cm}$ thick all along the eight vines of each experimental plot. The remains of the residues were withdrawn from the other half to outside the trial area.

Rye plant samples were taken immediately before each cutting of the cover crop, taking a quadrant of $1 \mathrm{~m}^{2}$ $(1.0 \times 1.0 \mathrm{~m})$ randomly in each experimental plot. The plants were cut off to a height of $10 \mathrm{~cm}$ with clippers simulating the cutting of a mechanical mower. Once cut, the plants from the quadrant were placed in paper bags and taken to the laboratory in Santiago (INIA-CRI La Platina) where they were separated botanically. Once identified and counted, plant samples were dried in a forced air oven at $60{ }^{\circ} \mathrm{C}$ for approximately $15 \mathrm{~d}$ and thus dry matter (DM) content was determined.

Rye DM in Santiago was determined as in Los Andes, although the first biomass evaluation was conducted on 16 September and the second on 27 December 2004. Rye was mowed on two occasions, 20 September and 27 November 2004, when plants reached an average height of $1.0 \mathrm{~m}$. with a motorized manually operated mower (Gravely 10, Brillion, Wisconsin, USA). Rye plants were cut at a height of $10 \mathrm{~cm}$ approximately, and residues from both cover crop sides were left in situ or moved by raking to the ridge of the vine row, forming the vegetal mulch.

\section{Sampling of weeds}

Weed samplings in Los Andes were carried out on 9 October, 10 November and 10 December 1998, 8 January and 19 February 1999 , using a $1.0 \mathrm{~m}^{2}(1.0 \times 1.0 \mathrm{~m})$ quadrant which was also used to determine rye DM. Each sample was taken randomly from the grapevine row on each experimental plot, without repeating a previously sampled place. The procedure used for the identification, drying and determination of DM of sampled weeds was the same as that used with the rye samples. Randomly selected quadrants of $0.25 \mathrm{~m}^{2}(0.5$ $\mathrm{x} 0.5 \mathrm{~m}$ ) were used in Santiago. The procedure used for the identification, drying and determination of DM of the sampled weeds was the same as that used with rye samples. As in Los Andes, weeds in the quadrant were cut to ground level. Weed sampling dates were according to the plant growth and were made on 12 October 2004, 17 February 2005 and 22 March 2005.

\section{Herbicide application}

Herbicides were applied in Los Andes with a manuallyoperated backpack sprayer (Hardi, Model BP-20, Clifton upon Dunsmore, UK) with a 20 L plastic tank equipped with a aluminum bar with four plastic flat nozzles, operated at a constant pressure $(241 \mathrm{kPa})$ delivering an average of $200 \mathrm{~L} \mathrm{ha}^{-1}$ and a spraying width of $1.5 \mathrm{~m}$. The chemical control treatment in Santiago consisted of systematic applications of non-selective herbicide (glyphosate) sprayed on 16 September and 27 December, as well as on the same dates as rye was mowed. A Hardi manually operated backpack sprayer with a $20 \mathrm{~L}$ capacity was used, operated at a constant pressure $(241 \mathrm{kPa})$, equipped with a single flat plastic nozzle with $0.5 \mathrm{~m}$ effective coverage width at $30 \mathrm{~cm}$ height. Each herbicide treatment was first applied along one side of the rows and then on the opposite 
side, spraying directly towards the weed foliage at an average speed of $3.5 \mathrm{~km} \mathrm{~h}^{-1}$.

In both trials flooding irrigation was used during spring and summer watering the complete vineyard, in accordance with the irrigation program of each grapevine producer. Orchard management practices were carried out conventionally, in terms of fertilizers, insecticides and foliar fungicides that were utilized by the producer.

\section{Experimental design and statistical analysis}

The experimental plots in Los Andes were located in one vineyard row with eight vines $(28.0 \times 1.0 \mathrm{~m})$ leaving a row on each side as a border between plots. The treatments were conducted in the field as randomized complete blocks (RCB) design with three replicates. The treatments in Santiago were also in a RCB design with four replicates. The experimental plots were composed of five Cabernet Sauvignon $(10.0 \times 1.0 \mathrm{~m})$ vines with vegetal cover of rye (between vine rows) on both sides, except the control row that received conventional chemical and mechanical treatments. The vine rows were planted on a ridge approximately $30 \mathrm{~cm}$ high and $1.0 \mathrm{~m}$ wide. A bordering row was left between each experimental unit.

The variance analysis (ANOVA) and means separation by Duncan's multiple comparisons test $(\mathrm{P}<0.05)$ were made using the program Statgraphics Plus 5.1 Professional (Statgraphics, 2006). In the case of weed DM samples with many values equal to zero or where weed plant data was highly variable due to its natural uneven distribution in the field, the values were transformed to $\sqrt{x}+1$, previously performing the variance homogeneity test.
In Los Andes, the experiment was conducted in a RCB design, where the analysis that included different sampling dates for rye and weeds were analized as a factorial RCB arrangement. Rye samples were analyzed as a $2 \times 3$ factorial arrangement (two covers and three sampling dates), and weeds were analyzed as a $4 \times 5$ factorial arrangement, where the first factor was the four treatments and the second factor was each of the sampling dates (9 October, 10 November, 10 December, 8 January and 19 February). The statistical analysis for the data in Santiago was carried out in the same manner, except that sample dates for rye ( 16 September and 27 November) and weeds (12 October, 17 February and 22 March) were incorporated for the analysis as a second factor within the factorial analysis.

\section{RESULTS}

The cutting criteria of the first trial in Los Andes, which was done monthly based on a given phenological stage of rye, proved to be inadequate because there was a high production in the first cutting and very low in the second and third cuttings. This criterion was corrected in Santiago and plant height was used, and in fact no differences in cover crop DM were observed in the two cutting dates (Table 1).

There was higher total DM production in Los Andes than in Santiago, probably owing to earlier sowing and better quality of soil used. In effect, the Santiago vines were established in a Mapocho series soil, with many stone patches, while in Los Andes was a Pocuro series soil, deeper and with a higher soil fertility levels. Nevertheless, the quantity of rye in both localities at the first spring cutting (16 September in Santiago and 6 October in Los Andes) was enough to form a solid and

Table 1. Rye dry matter production on each cutting date, subsequently used as vegetal mulch on grapevine row cv. Flame Seedless, Los Andes, Region of Valparaíso, 1998-1999, and cv. Cabernet Sauvignon, Santiago, Región Metropolitana, 2004-2005.

\begin{tabular}{lccc}
\hline \multirow{2}{*}{ Cutting date } & \multicolumn{2}{c}{ Rye dry matter } & \\
& Los Andes & Cutting date & Santiago \\
\cline { 2 - 4 } $03 / 10 / 1998$ & $384.5 \mathrm{a}$ & $16 / 10 / 2004$ & 229.8 \\
$04 / 11 / 1998$ & $80.4 \mathrm{~b}$ & $27 / 11 / 2004$ & $203.8 \mathrm{NS}$ \\
$02 / 12 / 1998$ & $196.5 \mathrm{~b}$ & & \\
Total accumulated & 661.4 & Total accumulated & 433.6 \\
& $\mathrm{CV}=31.0 \%$ & & $\mathrm{CV}=24.9 \%$ \\
\hline
\end{tabular}

Means with equal letters within the same column or row are not statistically different according to the Duncan test (5\%). NS: ANOVA indicated that there were not significant effects at the cutting dates according to the F test $(5 \%)$. 
firm mulch in vineyard rows. It is important to point out the rusticity of this cereal, which withstands very well in subfreezing winter temperatures, phenomenon widely described in the literature.

Dry matter production of yellow nutsedge from $\mathrm{cv}$. Flame Seedless vineyard rows are presented in Table 2. On the first two sampling dates ( 9 October and 10 November) there was a significantly lower nutsedge DM than in the following ones, indicating that high temperature to initiate growth of this species of tropical origin are required. The two chemical treatments did not differ in average weed control levels; nevertheless, significant date $\mathrm{x}$ treatment interaction was reflected precisely in that chemical treatment that included a specific herbicide for nutsedge was better than the treatment applied by the agricultural producer (glyphosate applied on 20 October and 29 December), in the sense that nutsedge DM production was significantly lower in the last two dates ( 8 January and 1 February). This was due to the application of halosulphuron + glyphosate mixture, which is specific for nutsedge control, performed on 4 December 1998 and especially on 25 January 1999 (Table 2).

On the other hand, there was an important effect of rye residues, given that where it was accumulated; a significant reduction in DM of nutsedge was achieved in comparison to the best chemical controls (Table 2). Even more, when these plant residues were accumulated on the grapevine tree row, forming a dense layer of mulch (T3 rye and mulch), the growth inhibiting effect on the nutsedge was even greater, given that this treatment had the lowest DM of this aggressive perennial weed. In effect, in comparison to the conventional treatment carried out by the producer, rye mulch allowed for reducing nutsedge DM by $84 ; 78$; and $77 \%$ in December, January and February samplings, respectively, reaching a mean reduction of $81 \%$ over the season ( 84.9 vs. 15.9 $\mathrm{g} \mathrm{m}^{-2}$ ). This is interesting from the viewpoint of control, indicating that this perennial weed is very sensitive to shading resulting from the plant much and/or that it is, as well, highly sensitive to growth inhibiting effects of hydroxamic acids (HX) of rye, concentrated in both on the aerial and subterranean residues, given that the cover crop was established all over the plantation surface, including the ridges where the vegetal mulch was subsequently formed.

The weed population at the Los Andes trial (Figure 1A) was composed of 16 species, of which and in order of decreasing importance were: deadnettle (Lamium amplexicaule L.), yellow nutsedge, shepherd's purse (Capsella bursa-pastoris (L.) Medik.), purslane (Portulaca oleracea L.), white goosefoot (Chenopodium album L.), knotgrass (Polygonum aviculare L.), bermudagrass, johnsongrass (Sorghum halepense (L.) Pers.) and gallant soldier (Galinsoga parviflora Cav.).

The use of herbicides in both chemical treatments, while serving to partially reduce DM of weeds, was not sufficiently effective to reduce the complete population (Figure 1A). The winter (deadnettle, shepherd's purse) and summer (goosefoot, gallant soldier) broadleaves

Table 2. Yellow nutsedge dry matter production on the grapevine row cv. Flame Seedless. Los Andes, 1998-1999.

\begin{tabular}{|c|c|c|c|c|c|}
\hline \multirow[t]{2}{*}{ Sampling date } & \multicolumn{4}{|c|}{ Weed control treatment } & \multirow[t]{2}{*}{ Mean dates } \\
\hline & $\begin{array}{c}\text { Chemical } \\
\text { control }\end{array}$ & Rye in situ & $\begin{array}{c}\text { Rye and } \\
\text { mulch }\end{array}$ & $\begin{array}{c}\text { Chemical and } \\
\text { mechanical }\end{array}$ & \\
\hline & \multicolumn{5}{|c|}{$\mathrm{g} \mathrm{m}^{-2}$} \\
\hline 09/10/1998 & $0.0 \mathrm{a}$ & $0.0 \mathrm{a}$ & $0.0 \mathrm{a}$ & $0.0 \mathrm{a}$ & 0.0 \\
\hline $10 / 11 / 1998$ & $6.0 \mathrm{a}$ & $1.4 \mathrm{a}$ & $0.0 \mathrm{a}$ & $6.5 \mathrm{a}$ & 3.6 \\
\hline $10 / 12 / 1998$ & $40.3 c$ & $6.3 \mathrm{a}$ & $4.8^{\mathrm{a}}$ & $30.0 \mathrm{c}$ & 23.0 \\
\hline 08/01/1999 & $16.5 b$ & $10.5 \mathrm{ab}$ & $5.8^{\mathrm{a}}$ & $26.0 \mathrm{bc}$ & 14.9 \\
\hline 19/02/1999 & $11.8 \mathrm{~b}$ & $13.8 \mathrm{~b}$ & $5.3 \mathrm{a}$ & $23.3 \mathrm{bc}$ & 12.7 \\
\hline Mean treatment & 18.6 & 8.0 & 3.9 & 21.4 & \\
\hline \multicolumn{6}{|c|}{$\begin{array}{c}\text { Treatment effect }(\mathrm{T})^{1} \\
\text { Sampling date effect }(\mathrm{F})^{1} \\
\mathrm{~T} \times \mathrm{F}^{1} \\
\mathrm{CV}=16.0 \%\end{array}$} \\
\hline
\end{tabular}

Means with equal letters within the same column or row are not statistically different according to the Duncan test (5\%). ANOVA and Duncan test $(5 \%)$ were conducted with data transformed to $\sqrt{x}+1$, the values presented are the original ones. ${ }^{1}$ ANOVA indicated significant effects owing to the treatments according to the $\mathrm{F}$ test $(1 \%)$. 
species tended to escape glyphosate control, contributing greatly to increase the total accumulated DM over time. Likewise, bermudagrass also contributed to this total weed DM volume, given that it is one of the most difficult perennial species to control with the rates of glyphosate used in this trial. It is interesting to note that rye significantly reduced the total weed DM, even at levels lesser than half of those reached with both chemical control treatments. In effect, rye mulch not only allowed for a significant reduction on the nutsedge

\section{Los Andes}

$\mathbf{A}$
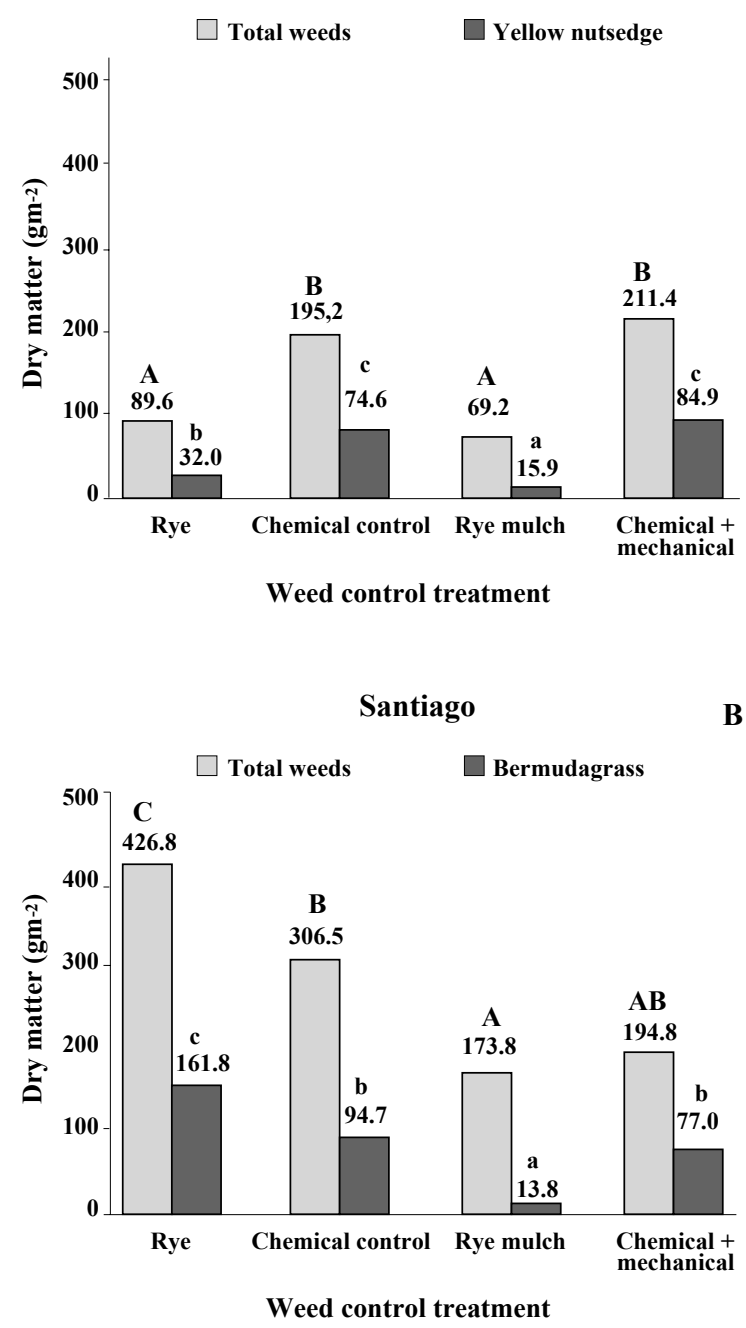

Figure 1. Total weed dry matter production at the end of the season on the grapevine row. (A) Yellow nutsedge in cv. Flame Seedless, Los Andes, 19981999; (B) Bermudagrass in cv. Cabernet Sauvignon, Santiago, 2004-2005.

Dry matter column values with the same capital or lower case letters are not statistically different, according to the Duncan test (5\%). growth, but also inhibited the growth of all weed species (including broad-leaved weeds) by $67.3 \%$ in comparison to the conventional chemical-mechanical treatment carried out by the producer (211.4 vs. 69.2 $\mathrm{g} \mathrm{m}^{-2}$, Figure 1A).

The weed population at the Santiago trial was composed by broad-leaved and grass species. Grass weeds represented almost $60 \%$ of the total weed DM and were composed by six winter and summer species, but bermudagrass represented $70 \%$ of the observations in the trial. On the other hand, the broad leaf group represented $40.4 \%$ of DM and was composed of 18 winter and summer species, of which the most important were: prickly lettuce (Lactuca serriola L.), wild turnip (Brassica spp.), bristly oxtongue (Picris echioides L.) and field bindweed (Convolvulus arvensis L.), which together constituted $61.2 \%$ of the broad-leaf species.

Table 3 presents bermudagrass DM determined in Santiago trial. This weed appeared in important quantities in the first collection date (12 October), indicating that, despite its tropical origin, it has adapted to the temperate winter of the central zone of Chile. The chemical controls based on two spring applications of $1 \%$ glyphosate significantly reduced Cynodon DM on the grapevine rows and there were no significant differences between the two chemical treatments used, although the inter-row of one of these had a rye cover. The treatment consisting of rye mulch deposited and accumulated on ridge of the vine row effectively reduced growth of bermudagrass (Table 3 ). In this manner, in comparison to the conventional chemical-mechanical control treatment carried out by the producer, rye mulch on the rows reduced weed growth in the season by $82 \%$ based on DM (77.0 vs. $13.8 \mathrm{~g} \mathrm{~m}^{-2}$, Table 3).

To understand the conditions of competition of the vines, Figure 1B presents the volume of MS accumulated from all of the weeds that emerged in the ridge of the grapevines in Santiago. Glyphosate significantly reduced weeds in relation to the untreated treatment; nevertheless, the levels of reduction in the season were only 28 and $54 \%$ in the treatments with herbicides only and herbicide plus mechanical control in the inter-rows, respectively. These control levels were insufficient from a commercial point of view, indicating that glyphosate should have been complemented with another herbicide specific for broad leaf and/or have increased the herbicide rate and frequency of the applications (Ormeño, 2005). On the other hand, although less than in the case of bermudagrass, the presence of rye mulch also reduced 
total weed DM by $59.3 \%$ in comparison to the control ( 426.8 vs. $173.8 \mathrm{~g} \mathrm{~m}^{-2}$ ) and by $43.3 \%$ in comparison to the chemical treatment using glyphosate (306.5 vs. $173.8 \mathrm{~g} \mathrm{~m}^{-2}$ ) (Figure 1B).

\section{DISCUSSION}

While it is widely recognized that rye residues reduce weed growth, whether as a live plant cover crop or as residues applied as plant mulch (Masiunas, 2006), there are few studies conducted on vineyards and less with rye acting on specific perennial weeds. One of the exceptions is the work of Bordelon and Weller (1997), which studied the effect of covers on the first year of vineyards established in Indiana, USA. The greatest reductions achieved with 'Wheeler' rye were $82 \%$, but negative effects were produced on recently established vine (Vitis labrusca L.), concluding that this weed control action would have been more effective with mature vines. Effectively, no adverse effects on vine growth were observed in these two trials, whether in visual evaluations or in pruned matter weight at the end of the productive cycle in autumn (Garfe, 2001; Pino, 2006).

The high degree of control achieved in the two trials differed from other works, indicating that vegetal covers does not have a totally satisfactory effect in the first year (Ingels and Klonski, 1998), and that the optimal control of plant mulch generally does not include more aggressive perennial weeds, since they can emerge through the residues and even prosper, even more because of the absence of competition from other annual species (Robinson, 1988; Elmore et al., 1998). Nevertheless, all these works are general reviews on the subject and none of them studied nor specifically cited rye as a source of residues, nor referred to bermudagrass and yellow nutsedge as species to be controlled by means of mulching rye.

The growth suppressing effect (50 to $70 \%$ of control) of the plant residues can be of physical type, impeding initial seed/propagule germination and subsequent development of weeds, and/or biochemical, produced by specific plant allelochemicals in the soil. Nevertheless, without considering the allelopathic effect, physical effect of rye straw plays a key role in the suppression of weed (Liebl et al., 1992; Ormeño, 1999), decreasing light incidence at the soil surface, which is a key factor for species sensitive to the lack of light as bermudagrass (Ott, 1983) and yellow nutsedge (Doll, 1983). In effect, in field trials with transparent polyethylene, the emergence and growth of nutsedge was reduced up to $85 \%$ (Majek and Neary, 1991; Patterson, 1998). Guglielmini and Satore (2004) demonstrated that a $41-50 \%$ reduction of light intensity inhibited biomass accumulation of Cynodon, reducing rhizomes length by $74-85 \%$. Consequently, these weed control results were not surprising, given that both weed species were effectively shaded by the dense rye mulch formed on the ridge of the grapevine tree plantation.

Table 3. Bermuda grass dry matter production on the grapevine rows cv. Cabernet Sauvignon. Santiago, 2004-2005.

\begin{tabular}{|c|c|c|c|c|c|}
\hline \multirow[t]{2}{*}{ Sampling date } & \multicolumn{4}{|c|}{ Weed control treatment } & \multirow[t]{2}{*}{ Mean dates } \\
\hline & $\begin{array}{l}\text { Rye without } \\
\text { control }\end{array}$ & $\begin{array}{c}\text { Rye and } \\
\text { herbicide }\end{array}$ & $\begin{array}{l}\text { Rye and } \\
\text { mulch }\end{array}$ & $\begin{array}{c}\text { Chemical and } \\
\text { mechanical }\end{array}$ & \\
\hline & & & $-\mathrm{g} \mathrm{m}^{-2}$ & & \\
\hline $12 / 10 / 2004$ & $70.6 \mathrm{~d}$ & $23.5 b$ & $5.4 \mathrm{a}$ & $3.9 \mathrm{a}$ & 25.8 \\
\hline $17 / 02 / 2005$ & $39.4 b c$ & $30.8 \mathrm{bc}$ & $8.4 \mathrm{a}$ & $47.1 \mathrm{c}$ & 31.4 \\
\hline $22 / 03 / 2005$ & $51.8 \mathrm{c}$ & $40.4 b c$ & $0.0 \mathrm{a}$ & $26.0 \mathrm{~b}$ & 29.5 \\
\hline Mean treatment & 53.9 & 31.6 & 4.6 & 25.7 & \\
\hline \multicolumn{6}{|c|}{$\begin{array}{c}\text { Treatment effect }(\mathrm{T})^{1} \\
\text { Sampling date effect }(\mathrm{F}) \mathrm{NS} \\
\mathrm{T} \times \mathrm{F}^{1} \\
\mathrm{CV}=30.5 \%\end{array}$} \\
\hline
\end{tabular}

Means with equal letters within the same column or row are not statistically different according to the Duncan test (5\%). ANOVA and Duncan test $(5 \%)$ were conducted with data transformed to $\sqrt{x}+1$, the values presented are the original ones. ${ }^{1} \mathrm{ANOVA}$ indicated that there were significant effects owing to the treatments in accordance with the F (1\%).

NS: ANOVA indicated that there were not significant effects owing to the treatments in accordance with the F test (5\%). 
The total biomass of rye in Los Andes was $659 \mathrm{~g} \mathrm{~m}^{-2}$, while in Santiago it was less, reaching only $428 \mathrm{~g} \mathrm{~m}^{-2}$ (Table 1). Nevertheless, total residues in both sites were similar to the average biomass of $500 \mathrm{~g} \mathrm{~m}^{-2}$ previously used to effectively inhibit weeds in the field (Ormeño, 1999). It should be considered that in both experimental sites rye residues were accumulated in the rows, increasing the growth inhibiting effect on the weeds emerging in the rows of the vineyards, If we add to this that freshly cut rye foliage contains potent allelopathic agents such as hydroxamic acids ( $\mathrm{Hx})$ (Pérez and Ormeño-Núñez, 1993; Collantes et al., 1997) the high quantity of plant material, together with the allelo-chemicals included in the cut off fresh foliage, could explain the high suppressive effect observed. The main forms of $\mathrm{Hx}$ in rye are DIBOA (2,4-dihidroxi1,4-(2H)benzoxazin-3-ona) and its degradation product BOA (benzoxazin-2-ona), DIBOA being the main form that is exuded (Pérez and Ormeño-Núñez, 1991). The Hx tends to accumulate in rye tissue, because of which its stubble is highly allelopathic (Schilling et al., 1986); nevertheless, both DIBOA and BOA persist in time beyond the rye residues on the soil surface, period estimated between 120 and $160 \mathrm{~d}$ (Yenish et al., 1995). The quantities of DIBOA in rye foliage are variable, depending on the variety and sampling date, but they tend to decrease as the plant ages, and are stimulated by the stress produced by mowing or cutting the foliage (Collantes et al., 1997).

While there are no studies in Chile on the variation of $\mathrm{Hx}$ in rye, the punctual values reported identify 'Forrajero' (Pérez and Ormeño-Núñez, 1991; 1993) as a cultivar with a high DIBOA content, in accordance with a recent comparative study of 10 varieties of rye in the United States (Reberg-Horton et al., 2005). It is possible that the use of successive cuttings of foliage (unchopped) at vegetative stage, as the fresh rye residues managed in these two trials, allows, on the one hand, for taking maximum advantage of the greater DIBOA content in the plants, and on the other hand, the concentration of these residues on vineyard rows as vegetal mulch formed with large pieces that degrade more slowly, were the factors that together explain the strong growth suppressive effect on bermudagrass and yellow nutsedge. This combined effect of physical and allelopathic actions, already cited in literature (Doll and Bauer, 1991; Liebl et al., 1992; Ormeño, 1999), is one of the major advantages of the use of rye residues.

\section{CONCLUSIONS}

The winter rye cover crops established between grapevine rows in autumn, and that through successive spring foliage cuttings allowed for accumulating sufficient plant residues (mean $500 \mathrm{~g} \mathrm{~m}^{-2}$ ) to form a dense plant mulch on the grapevine tree rows, produced inhibition of yellow nutsedge and bermudagrass growth, in an overhead trained grapevine plantation in Los Andes and a trellised vineyard in Santiago.

The high level of growth inhibition of bermudagrass and yellow nutsedge achieved in the vineyard rows was possibly due to the joint effects of allelopathy and shading produced by the rye mulch. In effect, the successive cuttings of rye foliage into pieces allowed for taking advantage of the allelopathic effects from $\mathrm{Hx}$ action (DIBOA) by concentrating fresh plant residues on the vineyard rows as a dense and durable mulch, factors that in conjunction contributed to drastically reduce the growth of these two difficult to control perennial weed species.

This system of weed control based on the use of rye as mulch on the vine rows is highly versatile, given that it can be applied to all types of deciduous woody perennial orchards and/or in winter recess. It is suggested to carry out field tests to further evaluate the degree of weed control achieved in both conventional and organic fruit production.

\section{R E S U M E N}

Inhibición del crecimiento de chufa (Cyperus esculentus L.) y pasto bermuda (Cynodon dactylon (L.) Pers.) con mulch vegetal proveniente de centeno (Secale cereale L.) en vides. Juan Ormeño-Núñez ${ }^{1 *}$, Gerardo Pino-Rojas ${ }^{2}$, y Farouk Garfe-Vergara ${ }^{2}$. En dos ensayos de campo (Los Andes 1998-1999 y Santiago 2004-2005) se determinó el efecto inhibitorio sobre chufa (Cyperus esculentus L.) y pasto bermuda (Cynodon dactylon (L.) Pers.) de residuos de centeno (Secale cereale L.) establecido en otoño entre las hileras de vides (Vitis vinifera L.) en parronal (cv. Flame Seedless) y espaldera (cv. Cabernet Sauvignon). Las siegas sucesivas del centeno formaron un mulch vegetal denso y duradero sobre las hileras de vides. El mulch orgánico fue un 81 y $82 \%$ más efectivo para controlar chufa y pasto bermuda, respectivamente, que el control químico (sobre la hilera) + mecánico (entre 
las hileras). Dos aplicaciones de glifosato (octubre/ diciembre) al $2 \%$ para chufa y $1 \%$ para pasto bermuda no fueron suficientes para controlar efectivamente las dos malezas. El grado de control del total de malezas fue 67,3 y 43,0\% más efectivo con el mulch vegetal que con los tratamientos químicos en Los Andes y Santiago, respectivamente. El alto control ejercido por el mulch de centeno se debió a que el crecimiento de los nuevos brotes de chufa y pasto bermuda fueron particularmente susceptibles al sombreamiento del mulch, formado antes de su emergencia primaveral y que permaneció hasta inicios del otoño, y a que la siega del centeno maximizó los efectos alelopáticos de esta variedad local de centeno. Se sugiere utilizar este tipo de manejo de las cubiertas vegetales y mulch para el control efectivo de malezas en otros frutales caducifolios tanto en huertos de agricultura convencional como orgánicos.

Palabras clave: mulch, cubierta vegetal, centeno, Cynodon dactylon, Cyperus esculentus, vides.

\section{LITERATURE CITED}

Barnes, J.P., and A.R. Putnam. 1983. Rye residues contribute weed suppression in no tillage cropping systems, J. Chem. Ecol. 9:1045-1057.

Barnes, J.P., A.R. Putnam, B.A Burke, and A.J. Aasen. 1987. Isolation and characterization of allelochemicals in rye herbage. Phytochemistry 26:1385-1390.

Bordelon, B.P., and S.C. Weller. 1997. Preplant cover crops affect weed and vine growth in first-year vineyards. HortScience 32:1040-1043.

Bottenberg, H., J. Masiunas, C. Eastman, and D.M. Eastburn. 1997. The impact of rye cover crops on weeds, insects, and diseases in snap bean cropping systems. J. Sustain. Agric. 9(2/3):131-155.

Collantes, H.G., E. Gianoli, and H.M. Niemeyer. 1997. Effect of defoliation on the patterns of allocation of a hydroxamic acid rye (Secale cereale). Environ. Exp. Bot. 38:231-235.

Doll, J.D. 1983. Control de Cyperus esculentus L. y Cyperus rotundus L. p. 100-112. Panel de Expertos en Ecología y Control de Malezas Perennes, Santiago, Chile. 28 de noviembre-2 de diciembre. Universidad Católica de Chile, Facultad de Agronomía, Santiago, Chile.

Doll, J., and T. Bauer. 1991. Rye: more than a mulch for weed control. p. 146-149. Proceedings of the 1991 Illinois Agricultural Pesticides Conference. (Abstract). Wisconsin Crop Improvement Association, Madison, Wisconsin, USA.

Elmore, C., D. Donaldson, and J. Smith. 1998. Weed management. p. 107-112. In Ingels, C., R. Bugg, G. McGourty, and P. Christensen (eds.) Cover cropping in vineyards: A grower's handbook. Publication 3338. University of California, Division of Agriculture and Natural Resources, Davis, California, USA.

FAO. 1986. Ecology and control of perennial weeds in Latin America. 381 p. FAO, Rome, Italy.
Garfe, V.F. 2001. Utilización del centeno (Secale cereale L.) como cubierta vegetal invernal y mulch en parronales para el control de chufa (Cyperus esculentus L.) y otras malezas comunes en el Valle de Aconcagua, V Región. 68 p. Tesis Ingeniero Agrónomo. Corporación Universidad de Aconcagua, Facultad de Agronomía, San Felipe, Chile.

Guglielmini, A., and E. Satore. 2004. The effect of noninversion tillage and light availability on dispersal and spatial growth of Cynodon dactylon. Weed Res. 44:366-374.

Ingels, C., and K. Klonski. 1998. Historical and current uses. p. 3-8. In Ingels, C., R. Bugg, G. McGourty, and P. Christensen (eds.) Cover cropping in vineyards: a grower's handbook. Publication 3338. University of California, Division of Agriculture and Natural Resources, Davis, California, USA.

Johnson, D.H., and R.E. Talbert. 1989. Chemicals control bermudagrass and johnsongrass without injury to 'Concord' grapes. HortScience 24:971-973.

Liebl, R., W. Simmons, W.L. Max, and E.W. Stoller. 1992. Effect of rye (Secale cereale L.) mulch on weed control and soil moisture in soybean (Glycine max L.). Weed Technol. 6:838-846.

Majek, B.A., and P.E. Neary. 1991. Selective wavelength transmitting mulch for yellow nutsedge control. p. 263-268. (Abstract). Brighton Crop Prot. Conf. Weeds, SurreyBrighton, Surrey, UK.

Masiunas, J.B. 2006. Rye as a weed management tool in vegetable cropping systems. p. 127-158. In Singh, H.P., D.R. Batish, R.K. Kohli (eds.) Handbook of sustainable weed management. Food Products Press, Binghamton, New York, USA. 
Ormeño, J. 1999. Manejo y control de malezas con plantas alelopáticas: centeno. p. 121-137. In Céspedes, C., y M. Carvajal (eds.) Agricultura orgánica. Ministerio de Agricultura, Instituto de Investigaciones Agropecuarias, Centro Regional de Investigación Quilamapu, Chillán, Chile.

Ormeño, J. 2005. Malezas de huertos frutales y vides: biología y control. Colección Libros INIA No 17. 113 p. Instituto de Investigaciones Agropecuarias, Centro Regional de Investigación La Platina, Santiago, Chile.

Ott, P. 1983. Biología y ecología de Cynodon dactylon (L.) Pers. 176 p. Panel de Expertos en Ecología y Control de Malezas Perennes, Santiago, Chile. 28 de noviembre-2 de diciembre. Universidad Católica de Chile, Facultad de Agronomía, Santiago, Chile.

Patterson, D. 1998. Suppression of purple nutsedge (Cyperus rotundus) with poliethylene film mulch. Weed Technol. 12:275-280.

Pérez, F.J., and J. Ormeño-Núñez. 1991. Difference in hydroxamic acid contents in roots and root exudates of wheat (Triticum aestivum L.) and rye (Secale cereale L.): possible role in allelopathy. J. Chem. Ecol. 17:1037-1043.

Pérez, F.J., and J. Ormeño-Núñez. 1993. Weed growth interference from temperate cereals: the effect of an hydroxamic acids exuding rye (Secale cereale L.) cultivar. Weed Res. 33:115-119.
Pino, G. 2006. Efecto de residuos de centeno (Secale cereale L.) sobre el crecimiento de pasto bermuda (Cynodon dactylon (L.) Pers.) en vides viníferas (Vitis vinifera L.). 96 p. Tesis Ingeniero Agrónomo. Universidad Santo Tomás, Escuela de Agronomía, Santiago, Chile.

Reberg-Horton, S.C., J.D. Burton, D.A. Danehower, G. Ma, D.W. Monks, J.P. Murphy et al. 2005. Changes over time in the allelochemical content of ten cultivars of rye (Secale cereale L.). J. Chem. Ecol. 31:179-193.

Robinson, D. 1988. Mulches and herbicides in ornamental plantings. HortScience 23:547-552.

Sainju, U.M., B.P. Singh, and W.F. Whitehead. 1998. Cover crop root distribution and its effects on soil nitrogen cycling. Agron. J. 90:511-518.

Schilling, D.G., L.A. Jones, A.D. Worsham, C.E Parker, and R.F. Wilson. 1986. Isolation and identification of some phytotoxic compounds from aqueous extracts of rye (Secale cereale L.). J. Agric. Food Chem. 34:633-638.

Statgraphics. 2006. Available at http://statgraphics.softonic. com (Accessed August 2006).

Yenish, J.P., A.D Worsham, and W.S. Chilton. 1995. Disappearance of DIBOA-glucoside, DIBOA, and BOA from rye (Secale cereale L.) cover crop residue. Weed Sci. 43:18-20. 